\title{
Humas Sebagai Stakeholder Sekolah Dalam Keterserapan Lulusan Siswa SMK Kesehatan Yannas Husada
}

\author{
Kamiliyah $^{1}$, Bambang Sigit Widodo ${ }^{2}$, Amrozi $^{3}$ \\ ${ }^{123}$ Universitas Negeri Surabaya, Indonesia \\ Kamiliyah.19005@mhs.unesa.ac.id.
}

\begin{abstract}
The purpose of this research is to find out the efforts made by public relations as a stakeholder in schools in the availability of vocational school graduates. This research used qualitative method with descriptive qualitative approach. Data collection techniques through (1) Observations, (2) Interviews, and (3) Documentation Studies. The results showed that (1) Public Relations made several special programs that had been prepared at the beginning and implemented in accordance with the planning, (2) The percentage of graduates of SMK Kesehatan Yannas Husada in the last three years was 20\% of students working, $55 \%$ of students continued their studies, and $25 \%$ of students did not or had not worked.
\end{abstract}

Keywords: Public relation, stakeholder, availability of graduates, vocational school.

Abstrak. Tujuan penelitian ini adalah untuk mengetahui upaya yang dilakukan hubungan masyarakat sebagai stakeholder di sekolah dalam keterserapan lulusan siswa SMK. Penelitian ini menggunakan metode kualitatif dengan pendekatan deskriptif kualitatif. Teknik pengumpulan data melalui (1) Observasi, (2) Wawancara, dan (3) Studi dokumentasi. Hasil penelitian menunjukkan bahwa (1) Humas membuat beberapa program khusus yang di telah disusun di awal dan dilaksanakan sesuai dengan perencanaannya, (2) Persentase keterserapan lulusan siswa SMK Kesehatan Yannas Husada dalam periode tiga tahun terakhir adalah $20 \%$ siswa yang bekerja, 55\% siswa yang melanjutkan pendidikan, dan $25 \%$ siswa yang tidak atau belum bekerja.

Kata Kunci: Humas, stakeholder, keterserapan lulusan, SMK.

\section{PENDAHULUAN}

Humas merupakan salah satu fungsi dari manajemen yang membentuk serta mengelola hubungan saling menguntungkan antara suatu organisasi dengan masyarakat luar (eksternal). Keberadaan humas dalam suatu instansi atau organisasi sangat penting. Humas merupakan semua bentuk komunikasi yang terencana, baik internal ataupun eksternal antara suatu komunitas dengan semua khalayaknya dalam rangka mencapai tujuan yang sama dengan berlandaskan saling pengertian.

Humas berfungsi untuk mewakili masyarakat kepada manajemen, serta manajemen kepada masyarakat sehingga tercipta arus komunikasi dua arah, baik informasi ataupun dalam hal administrasi. Humas harus dapat bertindak sebagai pemberi data atau informasi untuk mencegah adanya kesalahpahaman dalam penerimaan dan penyampaian informasi, membangun hubungan baik dengan masyarakat, serta berupaya dalam menyebarluaskan atau mempublikasikan suatu kegiatan kerja.

Humas merupakan fungsi manajemen yang membantu, menciptakan dan saling memelihara alur komunikasi serta kerja sama suatu organisasi. Bagi suatu organisasi, humas berperan penting dalam menjalin hubungan baik dan penyampai informasi, ide, kritik dan saran, serta pengetahuan kepada publik secara dua arah. Komunikasi secara dua arah 
merupakan tuntutan bagi seorang humas agar dapat mengubah suatu sikap, situasi, pendapat dan perilaku suatu kelompok atau perorangan agar dapat sesuai dengan tujuan organisasi yang diwakili.

Dalam suatu instansi seperti sekolah, waka humas ikut memiliki tanggung jawab besar dalam pembuatan program yang dijalankan sekolah. Pembentukan program yang di rencanakan di awal oleh kepala sekolah dan para wakilnya ini menentukan peningkatan keberhasil sekolah. Dalam hal ini tentunya tidak lepas dari bantuan dan kerjasama antar pihak dalam sekolah ataupun luar sekolah. Oleh karena itu, humas disini sangat berperan penting untuk mendapatkan perhatian dan dukungan dari pihak-pihak tersebut, baik pihak internal maupun eksternal.

Selain sebagai penyampai informasi yang baik dan benar, humas disekolah dapat dikatakan sebagai alat bagi sekolah untuk memperluas hubungan dengan masyarakat luar dan organisasi lainnya. Dengan adanya perluasan hubungan dengan organisasi atau instansi lain, akan mempermudah humas dalam menerima dukungan yang baik serta memperluas hubungan kerjasama antara sekolah dengan oraganisasi-organisasi tersebut. Suatu hubungan kerjasama antar suatu instansi atau organisasi sangat berpengaruh terhadap keberhasilan program-program yang dimiliki oleh suatu organisasi, begitupun dengan programprogram humas yang ada di sekolah.

Peran humas lainnya dalam suatu lembaga pendidikan yaitu sebagai pemberi informasi kepada para siswa-siswinya yang masih minim informasi terkait jenjang pendidikan lanjutan ataupun informasi tempat kerja. Bagi siswa tingkat SLTA infomasi mengenai pendidikan lanjutan dan tempat kerja yang sesuai dengan keahlian mereka itu sangat penting, khususnya bagi siswa SMK yang akan memilih untuk langsung bekerja setelah lulus sokolah. Informasi-informasi tersebut, dapat diperoleh humas sekolah dari hasil kerjasama yang dilakukan sekolah dengan organisasi atau instansi lain.

Hubungan masyarakat pada dasarnya bertujuan untuk menciptakan citra positif sekolah di masyarakat. Humas atau yang dalam bahasa Inggrisnya populer dengan sebutan Public Relations merupakan salah satu bagian dari kajian Ilmu Komunikasi yang paling pesat berkembang. Definisi menurut British Institute of Public Relations (IPR): "Public Relations adalah keseluruhan upaya yang dilakukan secara terencana dan kesinambungan dalam rangka menciptakan dan memelihara niat baik (good will) dan saling pengertian antara suatu organisasi dengan segenap khalayaknya".

Menurut Soegiardjo dalam

Gassing dan Suryanto (2016) Public relations adalah fungsi manajemen yang melakukan penilaian terhadap sikap publik, menyesuaikan kebijaksanaan tata kerja dari suatu organisasi atau perorangan dengan kepentingan publik dan melakukan program aksi untuk memperoleh pengertian dan persetujuan publik. Definisi tersebut hampir memiliki pengertian yang sama dengan definisi yang disampaikan oleh Grunig (1984:6) yang menyatakan bahwa Public Relations atau Humas adalah, "...the management of communication between an organization and its publics." (Humas adalah kegiatan manajemen komunikasi antara sebuah organisasi dengan berbagai macam publiknya). Dalam pengertian yang cukup singkat dan sederhana tersebut, ada beberapa kata kunci yang cukup penting, yaitu (1) manajemen, (2) komunikasi, (3) organisasi, dan (4) publik. Empat kata kunci inilah yang selanjutnya merupakan elemen dasar untuk memahami semua kegiatan kehumasan.

$$
\text { Sedangkan Ruslan dalam }
$$

(Nasution, 2010:11) mendefinisikan: "Manajemen hubungan masyarakat adalah 
suatu proses dalam menangani perencanaan,

pengorganisasian,pengkomunikasian serta pengkoordinasian yang secara serius dan rasional dalam upaya pencapaian tujuan bersama dari organisasi atau lembaga yang diwakilinya". Dalam suatu lembaga pendidikan, seorang praktisi humas yang berfungsi sebagai penyelenggara komunikasi dua arah (timbal balik) dituntut untuk bisa professional dalam mengelola informasi sehingga dapat terwujud citra yang positif bagi lembaga. Adapun fungsi humas yang lainnya di lembaga pendidikan antara lain:

1. Membina hubungan harmonis kepada public internal (dalam lingkungan lembaga pendidikan, seperti: dosen/guru, tenaga administrasi dan siswa) dan hubungan kepada public eksternal (di luar lembaga pendidikan, seperti : orang tua siswa dan diluar lembaga pendidikan).

2. Membina komunikasi dua arah kepada public internal (dosen/guru, karyawan dan mahasiswa/siswa) dan public eksternal (lembaga luar/instansi, masyarakat dan media massa) dengan menyebarkan pesan, informasi dan publikasi hasil penelitian dan berbagai kebijakan-kebijakan yang ditetapkan pimpinan.

3. Mengidentifikasi dan menganalisis suatu opini atau berbagai pesoalan, baik yang ada di lembaga pendidikan maupun yang ada di masyarakat.

4. Berkemampuan mendengar keinginan atau aspirasi-aspirasi yang terdapat dalam masyarakat.

5. Bersikap terampil dalam menterjemahkan kebijakan-kebijakan pimpinan dengan baik.

Definisi lain dari hubungan di sampaikan oleh Effendy (2002:23) yaitu, hubungan masyarakat adalah komunikasi dua arah antara organisasi dengan public secara timbal balik dalam rangka mendukung fungsi dan tujuan manajemen dengan meningkatkan pembinaan kerja sama pemenuhan kepentingan bersama. Sekolah harus bisa tetap menjaga hubungan baik atau interaksi dengan masyarakat dan menginformasikan kegiatan-kegitan sekolah kepada masyarakat agar masyarakat dapat berpartisipasi dengan kegiatan sekolah tersebut, dengan begitu sekolah tersebut dapat tetap diterima di tengah-tengah masyarakat.

Humas dalam menjalankan tugasnya tentunya tidak lepas dari dukungan para pemegang kepenting baik dari pihak dalam ataupun dari pihak luar sekolah. Pihak-pihak inilah yang menjadi alasan keberlangsungan dan kesuksesan suatu organisasi. Para pihak-pihak pemegang kepentingan ini disebut dengan stakeholder internal dan Stakeholder external. Pengelola hubungan dan para stakeholder memegang peranan penting pada saat terjadi krisis atau permasalahan pada suatu organisasi.

Menurut Rhenald Kasali dalam bukunya Manajemen Public Relation, stakeholder merupakan setiap kelompok yang berbeda di dalam ataupun di luar perusahaan yang memiliki peran dalam menentukan keberhasilan suatu perusahaan. Stakeholder sendiri merupakan sebuah frasa yang terbentuk dari dua kata yaitu, "stake" dan "holder". Kata "stake dapat diartikan sebagai "kepentingan", sedangkan "holder" diartikan sebagai "pemegang". Jadi stakeholder diartikan sebagai pemegang kepentingan. Definisi stakeholder menurut Freeman dan McVea (2001) adalah setiap kelompok atau individu yang dapat mempengaruhi atau dipengaruhi oleh pencapaian tujuan organisasi.

Secara umum stakeholder di bagi menjadi dua bagian yaitu, stakeholder internal dan stakeholder external. Stakeholder internal adalah sekumpulan orang yang berada di dalam ruang lingkup perusahaan atau organisasi. Stakeholder internal cenderung lebih mudah untuk dikendalikan dan pekerjaan untuk 
komunikasi intern bisa diserahkan kepada bagian lain seperti kepegawaian atau dirangkap langsung oleh eksekutif puncak. Stakeholder internal di lembaga pendidikan meliputi seluruh warga sekolah yang terdiri dari, ketua yayasan, kepala sekolah, waka sekolah, guru/staff, siswa dan wali siswa.

Sedangkan stakeholder external adalah seseorang yang berkepentingan terhadap perusahaan dan berada di luar perusahaan. Pihak-pihak diluar perusahaan tersebut sangat berpengaruh penting terhadap kehidupan dan keberlangsungan suatu perusahaan atau instansi. Adapun pihak-pihak stakeholder external di lembaga pendidikan seperti, pemerintah pusat, pemerintah daerah dan industri atau instansi lainnya.

Dalam mendapatkan dukungan kuat dari pihak-pihak tersebut, baik dari stakeholder internal maupun stakeholder external tentunya peran humas sangat dibutuhkan sebagai pengelola hubungan yang baik. Hubungan kerjasama yang baik antara pemerintah, masyarakat dengan sekolah menjadi kebutuhan dasar untuk kualitas pendidikan di suatu sekolah.

Sekolah menengah kejuruan merupakan salah satu pendidikan formal yang menyelenggarakan pendidikan kejuruan pada jenjang pendidikan menengah yang mengutamakan pengembangan kemampuan siswa untuk melaksanakan jenis pekerjaan tertentu. Pendidikan kejuruan merupakan sebuah wadah yg bertanggungjawab untuk menciptakan SDM yang memiliki suatu kompetensi atau bakat sehingga lulusannya dapat dengan mudah terserap di dunia industri.

Menurut Undang-Undang Sistem Pendidikan Nasional No.20 Tahun 2003, "SMK atau yang juga disebut pendidikan kejuruan merupakan pendidikan menengah yang mempersiapkan peserta didik terutama untuk bekerja dalam bidang tertentu". Rupert Evans (1978: 8) menedefinisikan bahwa pendidikan kejuruan adalah "part of educatin which make an individual more employable in one group ofoccupations than in another". Pendapat tersebut mengatakan bahwa pendidikan kejuruan merupakan bagian sistem pendidikan yang mempersiapkan lulusannya agar lebih mampu bekerja pada satu bidang pekejaan tertentu.

Sedangkan John F. Thompson dalam (Sutirman, 2013: 10), menyebutkan bahwapendidikan kejuruan adalah "pendidikan yang menyediakan pengalaman, stimuli yang dapat dilihat, kesadaran informasi, atau keterampilan psikomotorik, dan meningkatkan proses pengembangan kejuruan dari eksplorasi, menetapkan dan memelihara orang itu sendiridi pekerjaan".

SMK diselenggarakan dengan fungsi, tujuan dan standar kompetensi lulusan (SKL). Standar Kompetensi Llusan (SKL) merupakan suatu acuan yang digunakan untuk mengukur dan memberikan paparan secara jelas mengenai kompetensi yang harus dimiliki oleh siswa.

Lulusan SMK ialah seseorang yang tela menyeleaikan penidikan di SMK. Keterserapan lulusan SMK dapat diartikan sebagai tingkat atau persentase keberhasilan lulusan SMK untuk memasuki dunia kerja maupun pedidikan lanjutan yang sesuai dengan kompetensi keahlian yang telah di dapatkan di bangu SMK

SMK Kesehatan Yannas Husada yang berada di kota Bangkalan, Madura didirikan pada 31 Desember 2009 merupakan salah satu sekolah kejuruan dalam bidang kesehatan dengan pilihan jurusan keahlian yang paling lengkap di bandingkan dengan SMK Kesehatan lainnya. Jaminan mutu pengelolaan pendidikan di SMK Kesehatan Yannas Husada dibuktikan dengan predikat terakreditasi A oleh Badan Akreditasi Nasional Sekolah/Madrasah (BAN-SM) tahun 2014, dengan diterbitkannya Undang Undang No.36 tahun 2014 tentang tenaga 
kesehatan yang menyebutkan bahwa tenaga bidang kesehatan terdiri atas tenaga kesehatan dan asisten tenaga kesehatan serta rencana diterbitkannya Peraturan Mentri Kesehatan (PERMENKES) tentang Asisten Tenaga Kesehatan maka eksistensi lulusan SMK Kesehatan khususnya kompetensi keahlian Farmasi, Keperawatan dan Analis Kesehatan semakin diakui dan dilindungi oleh peraturan dan per-undang-undangan.

Berangkat dari pemikiran inilah maka mulai tahun pelajaran 2016/2017 SMK Kesehatan Yannas Husada Bangkalan menambah kompetensi keahlianya yakni disamping "farmasi" juga membuka kompetensi keahlian "keperawatan" dan "analis kesehatan" dengan tujuan menjamin tersedianya Asisten Tenaga Kesehatan yang trampil dan berkualitas serta mampu berperan dalam rangka meningkatkan derajat hidup sehat masyarakat Indonesia. Disamping itu SMK Kesehatan Yannas Husada Bangkalan mampu membuktikan komitmen 3 bisa-nya (bisa langsung bekerja,bisa kuliah kemana saja dan bisa kuliah sambil bekerja) pada setiap tahun kelulusannya.

Berdasarkan latar belakang yang di jelaskan diatas, humas sebagai pemangku kepentingan internal sekolah yang bertanggungjawab menjaga komunikasi baik dengan masyarakat luas atau dengan beberapa industri diharapkan dapat menjadi sebuah harapan bagi siswa dalam mendapatkan informasi terkait keterserapan kinerja dan memperoleh pekerjaan ataupun dalam memperoleh informasi terkait jenjang pendidikan lanjutan. Oleh karena itu yang menjadi fokus penelitian ini adalah bagaimana upaya hubungan masyarakat di SMK Kesehatan Yannas Husada sebagai bagian dari stakeholder sekolah dalam keterserapan lulusan SMK Kesehatan Yannas Husada.

\section{METODE}

Metode yang digunakan dalam penelitian ini adalah metode kualitatif dengan pendekatan deskriptif kualitatif. Data pada penelitian ini di peroleh dari hasil wawancara dengan informan dan dokumentasi arsip-arsip serta foto-foto yang mendukung data utama. Metode pengambilan data pada penelitian ini menggunakan tiga metode, yaitu:

\section{Observasi}

Dengan melakukan pengamatan langsung ke SMK Kesehatan Yannas Husada dibagian hubungan masyarakat yang berhubungan dengan pengarsipan DUDI dan MOU sekolah, di bagian BK yang berhubungaan dengan pengarsipan data lulusan siswa, penyediaan BKK (Bursa Kerja Khusus), Pelaksanaan PKL (Praktik Kerja Lapangan), dan kendalakendala pada manajemen Humas.

\section{Wawancara}

Metode wawancara dilakukan secara langsung pada staff-staff yang berhubungan dengan manajemen hubungan masyarakat, dengan melakukan pencatatan wawancara yang dilakukan pada saat wawancara dan dengan menggunakan rekaman audio (audio recorder) agar data yang diperoleh dapat digunakan untuk melengkapi informasiinformasi yang dibutuhkan untuk menyelesaikan suatu permasalahan yang ada dalam divisi, khususnya di divisi hubungan Masyarakat.

\section{Dokumentasi}

Metode dokumentasi ini digunakan agar dapat mempermudah peneliti dalam pembuatan instrumen dokumentasi yang berisi data-data suatu instansi lokasi penelitian yang sudah ditentukan. Metode dokumentasi berarti cara mengumpulkan data dengan mencatat data-data yang sudah ada ataupun dengan mengambil gambar yang terkait dengan data peneitian. Data-data yang sudah di kumpulkan ini dapat digunakan untuk mendukung data utama. 


\section{HASIL DAN PEMBAHASAN}

Segala perencanaan program kegiatan sekolah pastilah berhubungan dengan humas sekolah. Humas juga sebagai salah satu pemangku kepentingan internal sekolah berperan dalam proses perencanaan kegiatan di sekolah dan merancang program kerja yang akan di laksanakan oleh sekolah dengan tujuan yang baik dan jelas. Rancangan program kegiatan yang di rencanakan oleh humas tentunya sudah di ketahui dan di sepakati oleh semua pihak pengelola sekolah. Kegiatan humas sekolah bertujuan untuk meningkatkan citra sekolah dan sekaligus untuk mempromosikan sekolah kepada masyarakat luas.

Berdasarkan temuan penelitian di SMK Kesehatan Yannas Husada menunjukkan bahwa humas sekolah merancang beberapa kegiatan sekolah dalam upaya menarik minat masyarakat luar sekolah seperti:

1. Memberikan pembelajaran kesehatan gratis kepada masyarakat luar atau selain warga sekolah di setiap tahunnya.

2. Melaksanakan door to door atau yang biasa disebut dengan pengenalan lingkungan sekolah.

3. Melakukan kerjasama kelembagaan untuk melaksanakan atau mengajak dan mengawal kegiatan bersama.

4. Malakukan digital marketing yang rutin dilakukan dan terkontrol.

5. Berpartisipasi dalam menjadi fasilitator maupun pembinaan UKS di sekolahsekolah menengah ataupun sekolah dasar.

6. Melaksanakan program unggulan bagi seluruh siswa dalam membaca dan menghafal Al-Qur'an sehingga akan tercetak kader calon guru Al-Qur'an.

7. Menyediakan layanan bagi seluruh siswa terkait dunia kerja.

8. Menyediakan layanan baik bagi warga sekolah maupun masyarakat luar sekolah terkait layanan kesehatan.
Selain beberapa kegiatan yang di paparkan di atas, hubungan masyarakat di SMK Kesehatan Yannas Husada juga memiliki satu proram khusus yaitu BKK (Bursa Kerja Khusus). Proram BKK ini di tujukan untuk melayani konsultasi mengenai keterserapan kerja bagi siswa lulusan sekolah atau membimbing siswa yang akan melanjutkan pendidikan ke jenjang lanjutan. Selain itu, BKK juga menyediakan layanan kesehatan bagi warga sekolah maupun masyarakat luar seperti pemeriksaan kesehatan, konsultasi obat, serta juga melayanai pengobatan tradisional seperti candhuk atau bekam. Program tersebut di rancang dan dibina oleh waka humas sendiri dengan dibantu oleh beberapa staf dan guru disekolah.

Dari beberapa program-program humas di SMK Kesehatan Yannas Husada Bangkalan, pengadaan layanan bursa kerja khusus (BKK) merupakan salah satu program yang sangat menarik. Tidak banyak sekolah yang memiliki kegiatan pelayanan seperti BKK, yaitu membimbing, melayani, mengarahkan serta mendampingi siswa dalam menentukan langkah yang akan mereka ambil kedepannya. Kegiatan ini harus terus dikembangkan untuk meningkatkan kualitas lulusan di SMKS Kesehatan Yannas Husada. Selain itu, kegiatankegiatan khas di sekolah dapat meningkatkan citra seklah serta menarik minat masyarakat luar melalui perantara siswa dan wali siswa yang merupakan bagian dari stakeholder internal sekolah.

Dengan adanya program-program menarik yang dimiliki sekolah, selain dapat menarik minat masyarakat untuk melanjutkan pendidikan di SMK Kesehatan Yannas Husada juga dapat menarik perhatian industri lain khususnya dalam bidang industri kesehatan ataupun fasilitas kesehatan untuk menjalin hubungan baik dan bersedia untuk melakukan kerjasama dengan sekolah. Hal ini dapat dibuktikan dengan adanya MOU antara sekolah dengan beberapa fasilitas 
kesehatan baik yang berada di kota Bangkalan ataupun di kota lain seperti RSUD, RSU, PUSKESMAS, Apotek dan industri lainnya. Adanya kerja sama tersebut dapat mempermudah bagi siswa lulusan SMK Kesehatan Yannas Husada dalam memperoleh pekerjaan bagi mereka yang ingin terjun langsung ke dunia pekerjaan setelah lepas sekolah. Berikut adalah tabel jumlah keterserapan siswa lulusan SMK Kesehatan Yannas Husada.

Tabel. 1. Data Keterserapan Siswa Lulusan SMK Kesehatan Yannas Husada Periode Tiga Tahun Terakhir

\begin{tabular}{|c|l|c|c|c|}
\hline NO & Tahun Lulus & 2018 & 2019 & 2020 \\
\hline 1 & Siswa Bekerja & 8 & 23 & 6 \\
\hline 2 & $\begin{array}{l}\text { Siswa Lanjut } \\
\text { Kuliah }\end{array}$ & 31 & 33 & 40 \\
\hline 3 & $\begin{array}{l}\text { Siswa Tidak } \\
\text { Bekerja/Lainnya }\end{array}$ & 11 & 11 & 25 \\
\hline 4 & Total Siswa & 50 & 67 & 71 \\
\hline
\end{tabular}

Dari data siswa lulusan SMK

Kesehatan Yannas Husada diatas dapat disimpulkan bahwa siswa angkatan tahun lulus 2018 terdapat 8 siswa yang memilih untuk lansung bekerja, 11 siswa yang tidak bekerja dan 31 siswa yang memilih untuk melanjutkan pendidikan ke jenjang lanjutan dengan total keseluruhan siswa yaitu 50 siswa. Siswa angkatan tahun lulus 2019 terdapat 23 siswa yang memilih untuk lansung bekerja, 11 siswa yang tidak bekerja dan 33 siswa yang memilih untuk kuliah, total keseluruhan siswa adalah 67 siswa. Sedangkan pada angkatan tahun lulus 2020, terdapat 6 siswa yang memilih untuk lansung bekerja, 25 siswa yang tidak bekerja dan 40 siswa yang memilih kuliah, total keseluruhan siswa yaitu 71 siswa. Adapun presentase dari jumlah siswa yang bekerja, siswa yang kuliah, dan siswa yang tidak bekerja adalah sebagai berikut:

1. Persentase siswa lulusan tahun 2018 dengan total 50 siswa

a. Siswa yang bekerja: $16 \%$

$$
\frac{8}{50} \times 100=16 \%
$$

b. Siswa melanjutkan kuliah: $62 \%$

$$
\frac{31}{50} \times 100=62 \%
$$

c. Siswa yang tidak bekerja / lainnya: $22 \%$

11

$11 \times 100=22 \%$

50

Persentase Siswa Lulusan SMK

Kesehatan Yannas Husada Tahun

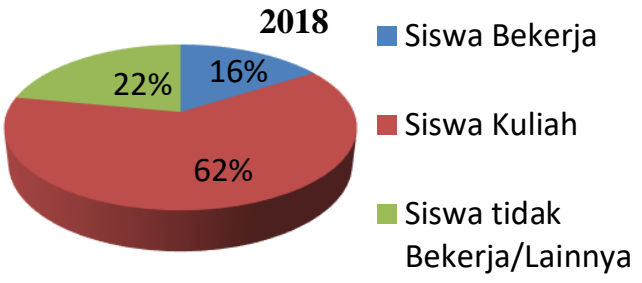

2. Persentase siswa lulusan tahun 2019 dengan total 67 siswa

a. Siswa yang bekerja: $34 \%$

$$
\frac{23}{6100}=34 \%
$$

67

b. Siswa melanjutkan kuliah: $49 \%$

$$
\frac{33}{67} \times 100=49 \%
$$

c. Siswa yang tidak bekerja / lainnya: $17 \%$

$$
\frac{11}{67} \times 100=17 \%
$$

67

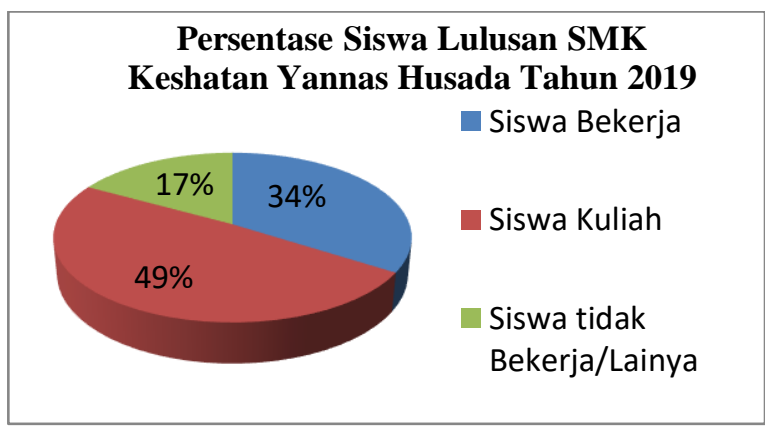

3. Persentase siswa lulusan tahun 2020 dengan total 71 siswa

a. Siswa yang bekerja: $9 \%$

$$
\frac{6}{71} \times 100=9 \%
$$


b. Siswa melanjutkan kuliah: $56 \%$

$$
\frac{40}{7100}=56 \%
$$

c. Siswa yang tidak bekerja / lainnya: $35 \%$

$$
\frac{25}{71} \times 100=35 \%
$$

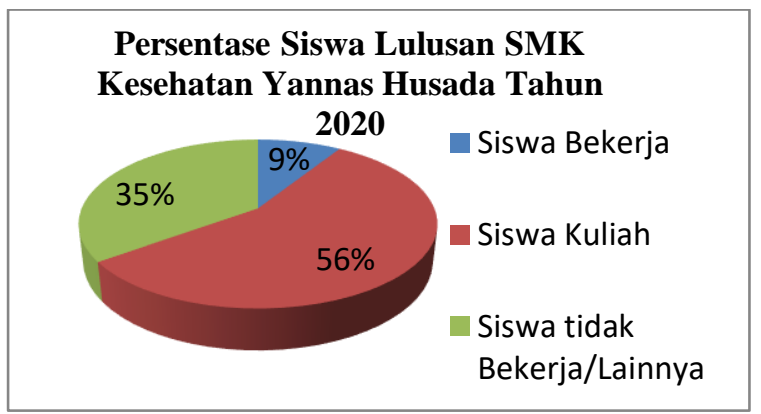

Total jumlah siswa lulusan SMK Kesehatan Yannas Husada periode tiga tahun terakhir adalah 188 siswa dengan total jumlah 37 siswa yang memilih langsng bekerja, 104 siswa yang melanjutkan pendidikan dan 47 siswa yang tidak bekerja atau belum bekerja. Sedangkan persetasenya adalah sebagai berikut:

a. Persentase siswa yang bekerja

$$
\frac{37}{188} \times 100=20 \%
$$

b. Persentase siswa yang melanjutkan kuliah

$$
\frac{104}{188} \times 100=55 \%
$$

c. Persentase siswa yang tidak bekerja/lainnya

$$
\frac{47}{188} \times 100=25 \%
$$

Total persentase siswa lulusan SMK Kesehatan Yannas Husada Periode Tahun 2018, 2019 dan 2020

$$
\begin{aligned}
& \text { Total siswa } \\
& \text { bekerja } \\
& \text { Total siswa kuliah } \\
& \text { Total siswa tidak } \\
& \text { bekerja/lainnya }
\end{aligned}
$$

\section{KESIMPULAN}

Berdasarkan hasil penelitian dan pembahasan, maka dapat disimpulkan beberapa hal yaiyu, Pertama, hmas merupakan penyelenggara komunikasi dua arah (timbal balik) dalam rangka mendukung fungsi dan tujuan manajemen dengan meningkatkan pembinaan kerja sama pemenuhan kepentingan bersama. Kedua, keberlangsungan dan kesuksesan suatu organisasi tidak lepas dari dukungan para pemegang kepetingan (stakeholder) yang memegang peranan penting pada saat terjadi krisis atau permasalahan pada suatu organisasi. Ketiga, dalam rangka menarik perhatian masyarakat luar serta meningkatkan kualitas siswa, humas SMK Kesehatan Yannas Husada merancang beberapa program menarik. Salah satu contoh programnya adalah program Bursa Kerja Khusus (BKK) yang merupakah salah satu program khusus yang dimiliki dan dikelola sendiri oleh sekolah yang di tujukan untuk melayani konsultasi terkait keterserapan kerja bagi siswa lulusan sekolah atau membimbing siswa yang akan melanjutkan pendidikan ke jenjang lanjutan serta pelayanan kesehatan. Keempat, berdasarkan paparan data diatas menunjukkan bahwa persentase keterserapan lulusan siswa SMK Kesehatan Yannas Husada dalam periode tiga tahun terakhir adalah $20 \%$ siswa yang bekerja, 55\% siswa yang melanjutkan pendidikan, dan $25 \%$ siswa yang tidak atau belum bekerja.

\section{SARAN}

Saran yang dapat di kemukakan oleh peneliti setelah melakukan penelitian ini adalah pimpinan sekolah dan para pemagang kepentingan sekolah diharapkan dapat mempertahakan bahkan meningkatkan pemberian dukungan khusus kepada humas dalam menjalankan program-program yang telah disusun, sehingga strategi dalam menarik minat masyarakat dan menjalin hubungan baik dengan masyarakat akan tetap terjaga. 
Selain itu, peneliti berharap sekolah dapat memiliki dunia usaha sendiri yang dapat dikelola dan ditujukan untuk siswa lulusan di SMK Kesehatan Yannas Husada sendiri. Hal ini dapat menjadi acuan bagi siswa untuk lebih meningkatkan kemampuan mereka sehingga kualitas lulusan di SMK Kesehatan Yannas Husada juga akan semakin baik.

\section{DAFTAR PUSTAKA}

Depdiknas. 2003. Undang-Undang RI No. 20 Tahun 2003 tentang Sistem Pendidikan Nasional.

Dhuhani, Elfridawati Mai. 2016. Manajemen Humas dalam Meningkatkan Mutu Madrasah Studi Kasus di Madrasah Ibtidaiyah Terpadu (MIT) AsSalam Ambon. Jurnal Al-Iltizam, Vol. 1 No. 1. Hlm. 31-54.

Ismail, Agung Deddiliawan., \& Anis Farida Jamil., \& Adityo. 2018. Manajemen Humas SMK Muhammadiyah 3 Wagir untuk Meningkatkan Kredibilitas Sekolah. Jurnal pengabdian masyarakat berkemajuan, Vol. 2 No.1. Hlm. 13-17.

Juhji., dkk. 2020. Manajemen Humas pada Lembaga Pendidikan. Bandung: Widina Bhakti Persada.

K. A. Mutaqin, Muhammad., \& Kusnawa, Wowo S., \& Sriyono. 2015. Studi Eksplorasi Keterserapan Lulusan Sekolah Menengah Kejuruan Negeri di Kota Bandung pada Industri Otomotif. Journal of Mechanical Engineering Education, Vol. 2, No. 2. Hlm. 247-252.Kholis, Nur., \& Zamroni., \& Sumarno. 2014. Mutu Sekolah dan Budaya Partisipasi Stakeholders. Jurnal pembangunan pendidikan:

Fondasi dan aplikasi, Vol. 2 No.

2. Hlm. 130-142.

Maulana, Rizal., \& Hengky Pramusinto. 2020. Strategi Humas Dalam
Menjalin Good Relationship dengan DU/DU. Economic Education Analysis Journal, Vol. 9 No. 1, Hlm. 228-242.

Nur Harini, Ira., \& Karwanto. (2014). Manajemen Hubungan Masyarakat dalam Upaya Peningkatan Pencitraan Sekolah (Studi Kasus di SMP Al Hikmah Surabaya). Jurnal Inspirasi Manajemen Pendidikan, Vol. 4 No. 4. Hlm. 8-20.

Rahmad, Abdul. 2016. Manajemen Humas Sekolah. Yogyakarta: Media Akademi.

Sutirman. (2013). Media dan ModelModel Pembelajaran Inovatif. Yogyakarta: Graha Ilmu.

Widodo, Hendro. (2017). Manajemen Perubahan Budaya Sekolah. Manageria: Jurnal manajemen pendidikan islam, Vol. 2 No. 2. Hlm. 287-306. 